cemoti $\begin{aligned} & \text { Cahiers d'études sur la Méditerranée } \\ & \text { orientale et le monde turco-iranien }\end{aligned}$

$38 \mid 2006$

Islam au Caucase

\title{
L'action des Fethullahci en Azerbaïdjan
}

Frédérique-Jeanne BESSON

\section{OpenEdition}

Journals

Édition électronique

URL : http://journals.openedition.org/cemoti/1547

DOI : $10.4000 /$ cemoti. 1547

ISSN : $1777-5396$

Éditeur

AFEMOTI

Édition imprimée

Date de publication : 20 février 2006

ISSN : 0764-9878

Référence électronique

Frédérique-Jeanne BESSON, «L'action des Fethullahci en Azerbaïdjan », Cahiers d'études sur la Méditerranée orientale et le monde turco-iranien [En ligne], 38| 2006, mis en ligne le 13 février 2006 consulté le 08 septembre 2020. URL : http://journals.openedition.org/cemoti/1547 ; DOI : https:// doi.org/10.4000/cemoti.1547

Ce document a été généré automatiquement le 8 septembre 2020

Tous droits réservés 


\title{
L'action des Fethullahci en Azerbaïdjan
}

\author{
Frédérique-Jeanne BESSON
}

\section{RÉSUMÉS}

Dès l'indépendance de l'Azerbaïdjan, la néo-confrérie nurcu dirigée par Fethullah Gülen a utilisé les trois leviers du commerce, de la presse et de l'éducation pour proposer et promouvoir un "modèle turc » de l'Islam. Son prosélytisme discret, s'appuyant principalement sur un réseau d'écoles privées, rencontre dans le pays un écho favorable tandis qu'il sert, bon gré mal gré, les intérêts de la politique extérieure turque. 